\title{
MEMOIRS
}

\section{REGINALD CLAUD SIMMONDS}

Reginald Claud Simmonds was born at Gravesend on 10 December 1888 and was educated at Clarence College and the Technical School in that town. He was appointed to the staff of the Law Accident in 1905 and transferred one year later to the Alliance, qualifying as a Fellow of the Institute in 1911. Apart from a period during the 1914-18 war, when he was commissioned in the Royal Garrison Artillery, he spent the rest of his professional career in the Alliance, being appointed Assistant Actuary in 1920, Actuary in 1929 and Actuary and Life Manager in 1939, posts which he occupicd successively with notable success until his retirement from the Company in 1949.

A man of quite exceptional gifts and industry, with a brilliant mind, a retentive memory and an extraordinary capacity for rapid work, he was able with ease not only to fulfil the commitments of his official duties and a considerable personal consultative practice, but to undertake much honorary and charitable work and meet the many demands made on his time and energy by the Institute. He occupied in turn with distinction almost every official position of the Institute. After playing a prominent part in the formative years of the Students' Society, of which he was Honorary Treasurer from 1914-19, and in later years Chairman from 1928-34, he served on the Council of the Institute for 23 years between 1926 and 1950 . In succession, he was Honorary Secretary 1930-32, Vice-President 1932-34. Treasurer 1942-44 and President 1944-46.

He took a particular interest in the educational work of the Institute, being Tutor in Compound Interest and Annuities-Certain from 1919-27 and a member of the Board of Examiners from 1928-31. He took part in the deliberations which led to the inauguration of the Actuarial Tuition Service in 1937 and was Chairman of the London Section from that date until 1944.

In his early years he was an avid reader of the English Classics and obtained much enjoyment from the works of John Ruskin, after whose cottage on Coniston Water, 'Brantwood', he named his first home. The influence of this master of prose can be seen in the literary style of Simmonds's writings for the Institute, which were many and varied in content. His first contributions were to the Students' Society, 'Analysis of Profit from a Practical Point of View' (J.S.S. 1(4), 5) and 'The Elementary Principles of a Pension Fund' (J.S.S. 1(5), 7) and in 'Twenty-five Years' (J.S.S. 4(5), 269) he became a historian of the Society, a role he was later to accept for the Institute. He read two papers before Sessional Meetings, 'Some Aspects of the National Insurance Act, 1911' (J.I.A. $1913,47,107$ ) and 'Notes concerning some practical points that arise in the valuation of Widows' Funds' (J.I.A. 1926, 57, 285). His other contributions to the Journal were 'Notes on the Mortality Experience of Missionaries of the Wesleyan Methodist Missionary Society' (J.I.A. 1917, 50, 137), 'The Work of George King', (J.I.A. 1933, 64, 241), 'The First Centenary of J.I.A.' (J.I.A. 1950, 76, 81) and his Presidential Address (J.I.A. 1946, 72, 140), an erudite work in his characteristic style, in which he discoursed on, among other matters, the training of actuaries, their conduct of affairs and the work available to them. But, of necessity, the Address had to contain a sombre note for, in the short period since his taking office, the Old Hall of Staple Inn had been destroyed by enemy action. His sorrow at this loss and his devotion to the Institute were movingly expressed in the following words with which he drew his Address to its close:

We can-we shall-rise superior to our pain and see the Institute in the measure of her renown and the full light of her opportunity. How shall I sing her majesty? 
Let me remove your instant apprehension, I do not use the word literally, it is a figure for speech. I should like to pay my tribute of love and hope in terms of my own framing, but I cannot find them. So I take words that were written in the great day of our English tongue, when Staple Inn Hall was in its first beauty. Some, I believe, would ascribe them to an errant philosopher-statesman who still lays upon actuaries the onus of trying to be a credit and whose namesake is honoured in our present counsels. Others prefer to think that the words were written by the man whose name they have borne for 300 years. It does not matter whose they were; they are ours and I believe that, as sign of life, not of arrested decay, they are apt to be spoken at this time of our homeless professional mother-our Institute of Actuaries-

Thou art not conquered; beauty's ensign yet

Is crimson in thy lips and in thy cheeks,

And death's pale flag is not advanced here.

In March 1945 he wrote a Memorandum on the Old Hall of Staple Inn, placing on record details of its destruction by enemy action and of the messages of sympathy received from kindred Actuarial Bodies (J.I.A. 1946, 72, 151).

Apart from his contributions to the Journal, he edited the Life Assurance Textbook and wrote a number of articles in it. He collaborated with T. P. Thompson in a revised edition of the Institute of Actuaries Textbook on Compound Interest and AnnuitiesCertain by Ralph Todhunter. His last great work for the Institute was The Institute of Actuaries 1848-1948, an account of the Institute of Actuaries during its first one hundred years, a work which entailed a vast amount of research and was produced at great speed. The review (J.I.A. 1948, 74, 379) states

The result is a fascinating study, well told with a fine sense of balance, a generous assessment of motive and illuminating flashes of humour,

and closes with the following:

The profession is much in the debt of the author, to whom the invitation of the Council to act as the historian of the Institute must have implied a high compliment, a heavy responsibility, an arduous labour even if of love, and, at every stage, a race against time. It is a tribute to the author and publishers alike that this race was won and that, thereby, the volume was made available well before the opening date of the Centenary celebrations, to which occasion it made a valuable and attractive contribution. The author has a happy gift of quotation and we may apply to him a quotation with which, in another connexion, he has beguiled us:

Rare as epic song is the man who is thorough in what he does, and happily so; for he subjugates us, and makes us bondsmen to his ashes.

Possessed of the qualities that go to make an interesting and congenial companionamong them a facile wit, a fine sense of humour and a fund of quotations that he delighted to produce at appropriate moments-it was natural that he should be a popular participant in the various social activities connected with the Institute. He was one of a group of young actuaries who, in 1919, commenced to meet after the Sessional Meetings to dine and converse and was, with his companions, elected to the Gallio Club in 1920. He was Honorary Secretary and Treasurer of the Club 1927-37 and Chairman 1938-39. Elected to the Actuaries Club in 1929, he was Chairman 1947-48.

His activities outside the Institute were numerous. He was Chairman of the Life 
Offices' Association 1939-40, and he served as a member of the Governmental Committee to review Income Tax Treatment of Superannuation and Pension Schemes in 1950; many annuitants have reason to be grateful for the improvement in the tax position of annuities brought about as a result of the recommendations of this Committee and it is not too much to assume that this improvement is probably largely due to his influence. Among the honorary positions he occupied were those of Actuary to the British Legion Prince of Wales' Pension Fund and Actuary to the Royal United Kingdom Beneficent Association. As a member of the committee of this latter organization he took a keen practical interest in the management of its homes for the elderly.

He was a man of deep religious faith, to which he was always willing to give practical expression. Having family connexions with the ministry of the Methodist Church, he was in early life a member of that Church, acting frequently as a lay preacher. In 1934 he took a prominent part in the formation of the Methodist Sacramental Fellowship, of which he was Honorary Secretary until 1949, since when, until his death, he was a VicePresident. The Society had for one of its main objectives reunion with the Anglican Church, and its influence in moulding Methodist opinion has undoubtedly helped towards the conversations on reunion now taking place between those two churches. After going to reside in the village of Fawkham in 1938, he was confirmed into the Church of England and later became a Churchwarden of the Parish. During his period of office, the interior of the Norman Parish Church was restored and beautified, in the organizing of which he played a prominent part.

In 1913 he married Ada Elizabeth Sharp, a gifted lady who had the distinction of having a picture, which she painted when she was 78 , hung in the Royal Academy. She predeceased him by two years. These two years were marred for him not only by grief for her loss, but by persistent ill-health and much physical suffering which were borne, as those who knew him would expect, with patience and fortitude. He dicd on 11 March 1969 and so passed from our scene a loyal and talented son of the Institute, who in his lifetime worthily carried out the principles enshrined in her Baconian Motto.

V. W. TYLER

\section{WILLIAM ROBERT MOORE}

WILliam ROBERT MOORE died on 5 March 1969 at the age of 76 . He commenced his career in 1909 with the Norwich Union Life but in 1914 he transferred to the Phoenix, with which Company he remained to the end of his business life.

His Phoenix career was soon interrupted by the outbreak of the First World War during which he served in France with distinction, gaining the Military Cross in 1916 for great gallantry in leading a bombing party. Later he was wounded in the leg during the Battle of the Somme.

After the War, Moore resumed his service in the Phoenix mortgage department and also his actuarial studies, becoming a Fellow of the Institute in 1920. In 1923 his career took on a wider aspect, leading to his transfer to the Bristol branch of the Phoenix in 1927 where he served for nearly seven years, first as Assistant Manager and then as Manager. In 1934 he returned to London in the more conventional role of Assistant Actuary and became Life Manager and Actuary in the following year. This position he held for twelve years until his appointment as Deputy General Manager in 1947 and he remained as the second executive officer of the Phoenix until his retirement in 1956.

Moore served for two periods on the Council of the Institute-1938-41 and 1943-49. He was a member of the Actuaries Club (Chairman 1951-53) and also of the Gallio and Fellowship Clubs. He was a founder member of the latter and President in 1938. 